where Elderton is shown seated as one of a group of four; the characteristic attitude in which he is portrayed is one which brings back vivid memories of him. The picture is reproduced in colour in Equitable Assurances by M. E. Ogborn, which was published in the summer. I like also the profile of Elderton which appears on the gold medal; the sense of fun which was never far away has been caught very happily by Bayes. The photograph of Elderton reproduced with this memoir was taken when he was in his fifties.

H. J. TAPPENDEN

\title{
JOHAN FREDERIK STEFFENSEN
}

STEFFENSEN was one of those who ' warmed both hands before the fire of life'. He kept his faculties in full to the end of his 88 years and he was with his friends in the Danish Actuarial Society only five days before his death on 20 December r $96 \mathrm{r}$. A sudden heart attack took him and left a host of friends in many countries glad for his life, and sad for their loss.

Steffensen was born on 28 February 1873 , in Copenhagen, the son of the Supreme Judge of the Danish Army, and he, himself, took his degree in law at the University of Copenhagen. But after a short period in Fredericia, he returned to Copenhagen to begin his career in insurance, at first in re-insurance and later in the official board which supervised insurance. The mathematical nature of the problems involved in insurance led him to develop his mathematical talents, which were superb-he was self-taught in this subject. In I912, he gained his Ph.D. at the University of Copenhagen for a study in the theory of numbers.

After three years as managing director of a mutual life assurance society, he found his life's work in the teaching of insurance mathematics. He was the lecturer in this subject at the University of Copenhagen from 1919 to 1923 and Professor of Insurance Mathematics there from I923 to 1943. But the teacher was not divorced from the practical man of affairs. Steffensen was a member of the Danish Life Insurance Council from 1926 to 1929, when he joined the Board of Statsanstalten for Livsforsikring (the oldest Danish life office, an iristitution established by state guarantee), being Chairman of the Board from I94I to 195 I.

Yet notwithstanding these responsibilities, Steffensen found time for research in various fields of mathematics, the complete tally of his scientific publications comprising 107 items, the first in 1904 and the last in 1957 . His more important works included the theory of statistics (1923), interpolation (1925), insurance mathematics (1934) and the calculation of interest (1936). His work displayed a clarity of thought which revealed the pure mathematician, whatever the subject. The book on interpolation, for example, was a thorough treatment of a subject which would have received more attention had mechanical methods of calculation developed less rapidly. His contributions to pure mathematics went well beyond the fields of the ordinary statistician, and to his own original contributions, he added the joint editorship (for Denmark) for thirty years of Skandinavisk Aktuarietidskrift.

It is little wonder that his ability was recognized throughout the Scandinavian countries and beyond. He was President of the Danish Actuarial Society in 1922-24 and 1930-33, and of the Danish Mathematical Society in 1930-36; both 
Societies made him an honorary member, as also did the Swedish Actuarial Society and the Statistical Society of Czechoslovakia. The University of Sorbonne invited him to lecture in Paris in $193 \mathrm{I}$.

Steffensen had close connexions with this country. His marriage to an Englishwoman, Annie Caroline, the daughter of Albert Chesterfield Jenour, made him as much at home in England, both physically and in the English language, as in his own country and tongue. His friends here delighted to honour him; he was an honorary member of the Royal Statistical Society and received the rare distinction of becoming a Fellow of the Institute of Actuaries by election.

The University of London invited him in 1930 to lesture on his researches in the theory of statistics and actuarial science. His lectures gave insights into the depths that might be hidden in apparently simple problems; he graciously presented the copyright to the Institute of Actuaries and the lectures were published undcr its auspices. A personal recollection is of his ready help with the derivation of a formula for the rate of interest in an annuity-certain, stated without proof in an eighteenth-century work by William Jones, F.R.S. Steffensen, in a few lines, showed how the expression should be expanded in powers of $i$, when the term involving $i^{3}$ disappeared and the higher powers could be neglected, leaving a quadratic which was the basis of the solution.

His mastery of English and his love of English literature, especially Shakespeare, was shown at the Centenary Assembly of the Institute of Actuaries in 1948. In the course of a discussion, he remarked that when a certain professor and he went out shooting sparrows, the professor took a cannon whereas he himself took a shot-gun; he hoped both hit the sparrows! Few present were unmoved when at the closing ceremony he referred to the hardships of the war years and quietly said 'these few days have been to us like a Midsummer Night's Dream, which we shall always remember'.

A treasured possession was a copy of 'The Young Visiters' by Daisy Ashford, written with a childish whimsicality which greatly appealed to him. His own kindly sense of fun can be illustrated by a remark of his in reply to a lady who thought she had mistakenly called him Dr Steffensen, when she should have said Professor; he said 'Please call me Dr - that title cost me a lot of hard work!'

His last visit to London was in 1955 for the celebrations of the return of the Institute of Actuaries to its traditional home in Staple Inn-but he was proud to come privately, in his own right as Fellow, and no longer as a guest.

Steffensen, himself, was a modest man but should be ranked among the great.

M E OGBORN 